\title{
Review on iron availability in soil: interaction of Fe minerals, plants, and microbes
}

\author{
Claudio Colombo • Giuseppe Palumbo • Ji-Zheng He • \\ Roberto Pinton • Stefano Cesco
}

Received: 26 April 2013 / Accepted: 14 October 2013 / Published online: 30 November 2013

(C) Springer-Verlag Berlin Heidelberg 2013

\begin{abstract}
Purpose The rationale of this paper is to review the state of the art regarding the biotic and abiotic reactions that can influence Fe availability in soils. In soil, the managementinduced change from oxic to anoxic environment results in temporal and spatial variations of redox reactions, which, in turn, affect the $\mathrm{Fe}$ dynamics and $\mathrm{Fe}$ mineral constituents. Measuring the $\mathrm{Fe}$ forms in organic complexes and the interaction between bacteria and $\mathrm{Fe}$ is a major challenge in getting a better quantitative understanding of the dynamics of $\mathrm{Fe}$ in complex soil ecosystems.

Materials and methods We review the existing literature on chemical and biochemical processes in soils related with the availability of $\mathrm{Fe}$ that influences plant nutrition. We describe $\mathrm{Fe}$ acquisition by plant and bacteria, and the different $\mathrm{Fe}-$ organic complexes in order to understand their relationships and the role of $\mathrm{Fe}$ in the soil carbon cycle.

Results and discussion Although total $\mathrm{Fe}$ is generally high in soil, the magnitude of its available fraction is generally very low and is governed by very low solubility of Fe oxides.
\end{abstract}

Responsible editor Hailong Wang

C. Colombo $(\bowtie) \cdot$ G. Palumbo

Dipartimento Agricoltura Ambiente Alimenti, University of Molise,

Via De Sanctis, Campobasso, CB 86100, Italy

e-mail: colombo@unimol.it

J.-Z. He

Research Centre for Eco-environmental Sciences, Chinese Academy of Sciences, 18 Shuangqing Road, Beijing 100085, People's

Republic of China

\section{R. Pinton}

Dipartimento di Scienze Agrarie e Ambientali, University of Udine, Via delle Scienze 206, Udine 33100, Italy

S. Cesco

Faculty of Science and Technology, Free University of Bolzano-

Bozen, Piazza Università 5, Bolzano 39100, Italy
Plants and microorganisms can have different strategies in order to improve Fe uptake including the release of organic molecules and metabolites able to form complexes with $\mathrm{Fe}^{\mathrm{III}}$. Microorganisms appear to be highly competitive for Fe compared with plant roots. Crystalline Fe and poorly crystalline (hydro)oxides are also able to influence the carbon storage in soil.

Conclusion The solubility of crystalline Fe minerals in soil is usually very low; however, the interaction with plant, microbes, and organic substance can improve the formation of soluble $\mathrm{Fe}^{\mathrm{III}}$ complexes and increase the availability of Fe for plant growth. Microbes release siderophores and plant exudates (e.g., phytosiderophores, organic acids, and flavonoids), which can bind and solubilize the Fe present in minerals. The improved understanding of this topic can enable the identification of effective solutions for remedying Fe deficiency or, alternatively, restricting the onset of its symptoms and yield's limitations in crops. Therefore, development and testing of new analytical techniques and an integrated approach between soil biology and soil chemistry are important prerequisites.

Keywords Fe soil availability · Weathering of Fe-containing minerals $\cdot$ Microbial siderophores $\cdot$ Plant exudates

\section{Introduction}

Iron $(\mathrm{Fe})$ is an element relatively abundant in many cultivated soils with, on average, a total concentration of 20 to $40 \mathrm{~g} \mathrm{~kg}^{-1}$ (Cornell and Schwertmann 2003). In its ferrous ( $\mathrm{Fe}^{\mathrm{II}}$ ) state, $\mathrm{Fe}$ is mainly present in primary minerals and some phyllosilicates; its oxidation to the ferric form $\left(\mathrm{Fe}^{\mathrm{III}}\right)$ leads to important changes in pedogenetic processes (Torrent and Cabedo 1986; Adriano 2001; Stucki et al. 2002) resulting in the formation of a series of "conjugate bases" where Fe is 
coordinated with water and hydroxyls (Stumm and Furrer 1987; Cornell et al. 1989; Sposito 1989).

Among $\mathrm{Fe}$ pedogenetic forms of crystalline $\mathrm{Fe}$ (hydro)oxides, goethite $\left(\alpha\right.$-FeOOH) and hematite $\left(\alpha-\mathrm{Fe}_{2} \mathrm{O}_{3}\right)$ are the most abundant minerals in well-drained soil. Other $\mathrm{Fe}$ oxides may exist in poorly drained soil as crystalline minerals (lepidocrocite, maghemite, and magnetite), or short-rangeordered crystalline minerals (ferrihydrite and ferroxite) or noncrystalline precipitates (Schwertmann 1985; Cornell and Schwertmann 2003). The general rules governing the behavior of $\mathrm{Fe}$ are the redox potential (i.e., oxidizing or reducing conditions) and $\mathrm{pH}$. Neutral $\mathrm{pH}$ conditions promote the precipitation of poorly ordered $\mathrm{Fe}$ minerals (ferrihydrite), whereas reducing and acid conditions promote the mobilization of $\mathrm{Fe}$ minerals. Goethite and hematite are characterized by high stability (lower solubility) in the most habitual Eh-pH soil conditions. At a specific value of $\mathrm{pH}, \mathrm{Fe}$ oxides (hematites) and hydroxides (goethite) produce the same Fe concentration in a solution, while ferrihydrite only at a much lower Eh. However, in spite of their lower stability, metastable forms such as lepidocrocite and ferrihydrite often occur in many soils, particularly in younger soils characterizing the nonequilibrium state in the pedo-environment as cold climate and acidic soils (Schwertmann 1988). Small amounts of Fe minerals can also be found in reducing conditions in acid soil like pyrite $\left(\mathrm{FeS}_{2}\right)$ or in alkaline soil like siderite $\left(\mathrm{FeCO}_{3}\right)$.

Many crystalline and poorly ordered $\mathrm{Fe}$ species may interact with soil components such as inorganic and organic colloids to form even more complex aggregates with new surfaces (Colombo and Torrent 1991). The solubilization of $\mathrm{Fe}$ from soil mineral sources is a slow process regulated by $\mathrm{pH}$ and by the dissolution-precipitation phenomena of both crystalline and poorly ordered Fe-hydroxide minerals (Mengel
1994; Lindsay 1988). The solubility product of $\mathrm{Fe}$ carbonates is $3.2 \times 10^{-11}$ whereas the solubility product of $\mathrm{Fe}(\mathrm{OH})_{3}$ is $4 \times$ $10^{-38}$ (Lindsay and Schwab 1982). Therefore, the species of $\mathrm{Fe}$ in the soil environment could be summarized in the following: (1) $\mathrm{Fe}^{\mathrm{II}}$ in primary minerals; (2) $\mathrm{Fe}^{\mathrm{III}}$ in secondary minerals, as $\mathrm{Fe}$ crystalline minerals and poorly ordered crystalline (hydro)oxides; (3) soluble and exchangeable Fe; and (4) Fe bound to organic matter in soluble or insoluble forms (Fig. 1). As Fe participates in some life-sustaining processes of microbes and plants, it is considered an essential micronutrient and its availability is crucial for their growth. Under aerated conditions and $\mathrm{pH}$ values above 7 , it has been estimated that the total concentration of inorganic Fe species in the soil solution is around $10^{-10} \mathrm{M}$ (Boukhalfa and Crumbliss 2002), that is, $10^{4}-10^{5}$-fold lower than that required for an optimal growth of plants (Römheld and Marschner 1986). Therefore, Fe deficiency is a frequent problem for many crops, particularly in calcareous soils (Mengel et al. 2001). Since Fe geochemistry is strictly connected with physical, chemical, and biological processes occurring in soil (Carrillo-Gonzáles et al. 2006), factors influencing these processes could significantly affect the relative presence of the different $\mathrm{Fe}$ forms and, in turn, the micronutrient availability for the organisms (microorganisms and plants). As up to now several aspects related to these phenomena are still poorly understood, a more detailed knowledge concerning the processes involved in the Fe biogeochemistry in soil and of what could exert an impact favoring higher level of Fe availability for crops maintaining contemporarily the natural fertility of soils becomes relevant.

In this context, the present review will focus on the impact of microbes in association with plant roots and $\mathrm{Fe}$ minerals on the availability of $\mathrm{Fe}$ in soils. Since the acquisition of the
Fig. 1 Different species of iron oxides and hydroxides in soil. Chemical environment (potential redox and $\mathrm{pH}$ ) controls the $\mathrm{Fe}$ solubility primarily through the oxidation of the Fe-containing minerals. These species reach a minimum solubility near $10^{-10}$ in the $\mathrm{pH}$ range of $7.5-8.5$ while plants and microorganism require $<10^{-6} \mathrm{M} \mathrm{Fe}$ in solution

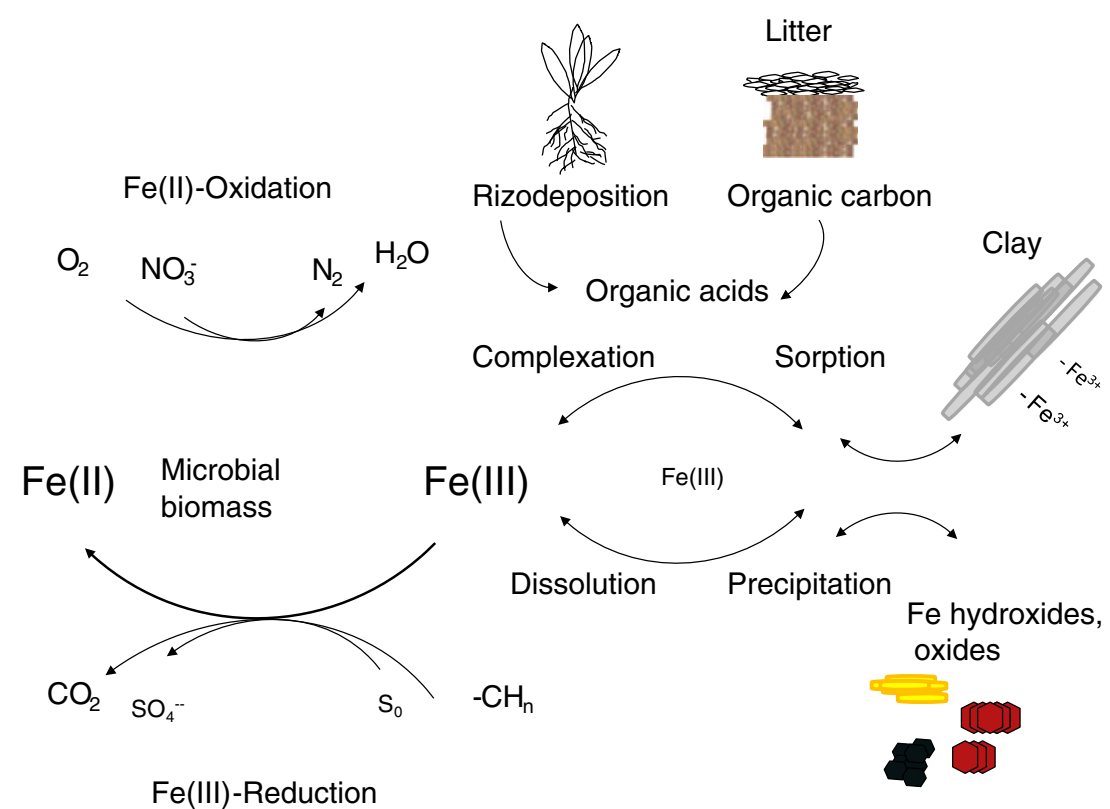


micronutrient by microbes and plants can play an important role in the equilibria among the different $\mathrm{Fe}$ forms in soil, mechanisms regulating these processes and their roles in alleviating $\mathrm{Fe}$ shortage will be discussed. Attention will be also paid to soil organic compounds whose accumulation and stabilization in soil is strongly related with the Fe biogeochemical cycle.

\section{$2 \mathrm{Fe}$ acquisition by plant and microbes: mechanisms and interactions}

Microbes and $\mathrm{Fe}$ oxides coexist in soils, and their close association provides ample opportunities for mutual interactions, where primary minerals may provide $\mathrm{Fe}$ and many other important nutrients like $\mathrm{P}$ and $\mathrm{S}$ in addition to appropriate habitats for microbes while microbes may influence mineral weathering (Lowenstam 1981; Lower et al. 2001). Ironcontaining primary minerals are specifically dissolved by bacteria (e.g., Thiobacillium and Metallogenium sp.), a weathering factor. These processes are strictly bacteria dependent and known as "sorption, solubilization (chelation), accumulation, transformation, precipitation". Within the rhizosphere, these mechanisms are even more complex because of the presence of plants. In fact, plants can affect microbes (abundance, diversity, and activity), Fe availability, and the interactions between Fe minerals and microbes as a consequence of root activity (exudation and nutrient uptake) to satisfy their need of this essential micronutrient. Therefore, the low supply of $\mathrm{Fe}^{\mathrm{III}}$ to the soil solution and the high demand of plants and microorganisms (for their intense growth) could induce a considerable level of competition for $\mathrm{Fe}$ in the rhizosphere (Loper and Buyer 1991; Guerinot and Yi 1994).

The principal means by which soil microbes acquire $\mathrm{Fe}$ in Fe deficiency relies on the synthesis and release of lowmolecular-weight Fe-binding molecules called siderophores (Fig. 2), $\mathrm{MS}_{\mathrm{s}}$ (see also the review of Lemanceau et al. 2009). For their high affinity for $\mathrm{Fe}^{\mathrm{III}}$ (Guerinot 1994), $\mathrm{MS}_{\mathrm{s}}$ are able to form $\mathrm{Fe}^{\mathrm{III}}$ complexes, which are then transported into microbial cells via specific $\mathrm{Fe}-\mathrm{MS}_{\mathrm{s}}$ membrane transporters (Neilands 1981). It is interesting to note that, despite the specific production of defined $\mathrm{MS}_{\mathrm{s}}$ by different microbial species, microbes have the capability to take up not only their own $\mathrm{MS}_{\mathrm{s}}$ but also those released by other species (Raaijmakers et al. 1995). Many aerobic microbes depend critically on their metabolites for the synthesis of these compounds (Lovley and Phillips 1986, 1988). $\mathrm{MS}_{\mathrm{s}}$ are lowmolecular-weight $(<1,000 \mathrm{Da})$ molecules and belong to a large group of Fe-binding molecules secreted by microbes in response to Fe deficiency. The $\mathrm{Fe}^{\mathrm{III}}-\mathrm{MS}_{\mathrm{s}}$ complexes are characterized by very high stability constant ranging from $10^{23}$ to $10^{52}$, values that are quite higher than those measured for $\mathrm{Fe}$ complexes formed by organic compounds frequently present in the rhizosphere like anions of organic acids (oxalate or citrate with stability constants of $10^{8}$ and $10^{11}$, respectively) or phytosiderophores released by grass roots $\left(\mathrm{PS}_{\mathrm{s}}, 10^{18}\right.$; Robin et al. 2008). $\mathrm{Fe}^{\mathrm{III}}-\mathrm{MS}_{\mathrm{s}}$ complexes even exhibit the same or even higher stability constants than Fe-EDDHA and $\mathrm{Fe}-$
Fig. 2 Contribution of Fe-chelation processes related to ligands released by microbes (siderophores $[M S]$ ) and plants (organic acids, phenols, and phytosiderophores $[P S]$ ) on $\mathrm{Fe}$ acquisition of roots (strategy I and strategy II plants) and microorganisms. The root utilization of $\mathrm{Fe}^{\mathrm{II}}$ produced by microbe-dependent redox processes is also reported

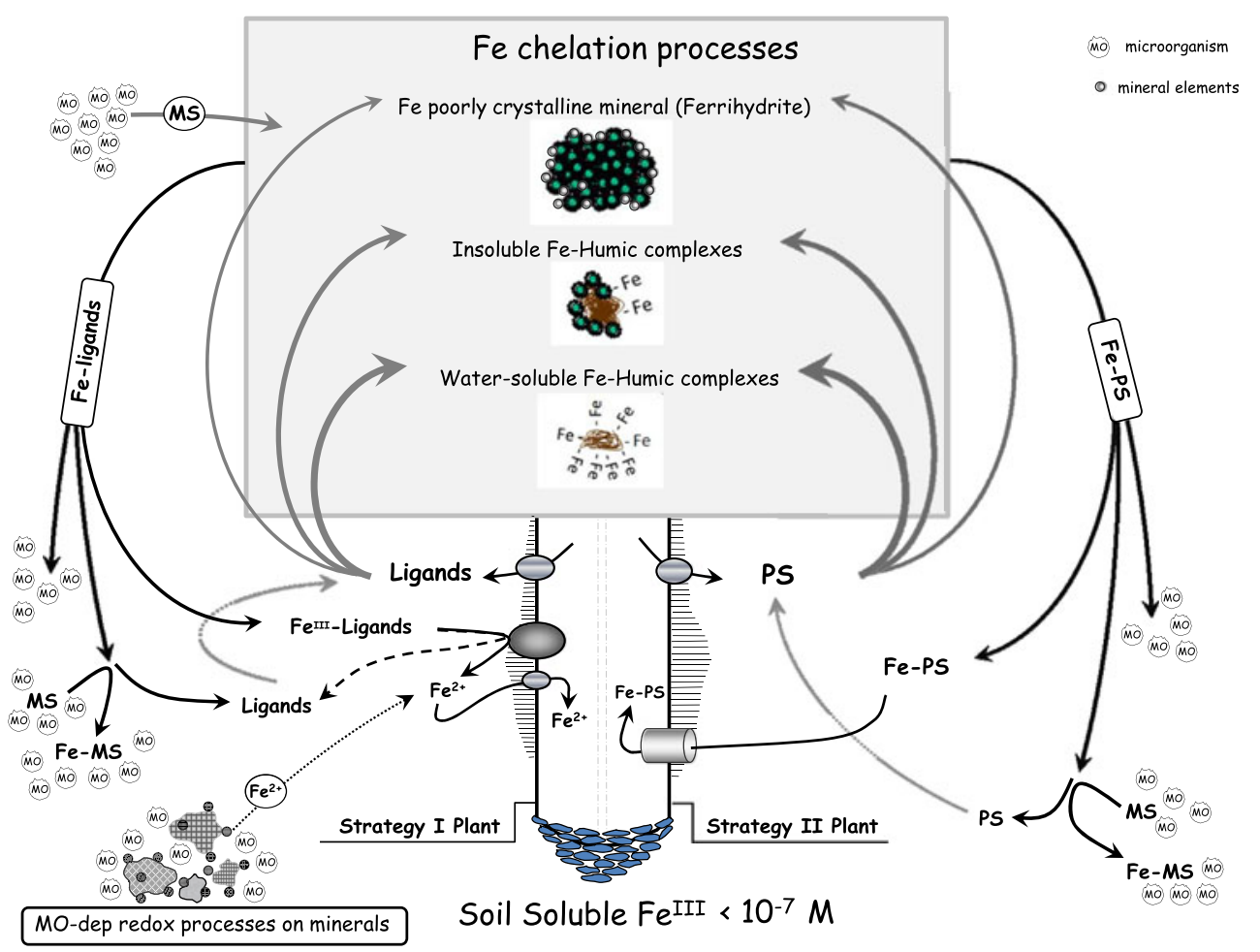


EDTA $\left(10^{33}\right.$ and $10^{25}$, respectively), which are synthetic Fe chelates commonly used in agriculture to cope with Fe deficiency in crops (Lucena 2000). For this very high stability of the Fe complex (Albrecht-Gary and Crumbliss 1998), $\mathrm{Fe}^{\mathrm{III}}$ $\mathrm{MS}_{\mathrm{s}}$ are considered efficient Fe carriers within the soil solution up to the root cells and through the cell wall.

For what concerns plants, to acquire Fe for their metabolism and growth, they have evolved active uptake mechanisms that differ between dicots (including also non-graminaceous monocots) and monocots (see also the review of Kobayashi and Nishizawa 2012). In the first case, the micronutrient is acquired by a reduction-based $\mathrm{Fe}$ uptake mechanism (strategy I, Marschner and Römheld 1994), which involves two steps: a reduction of $\mathrm{Fe}^{\mathrm{III}}$ to $\mathrm{Fe}^{\mathrm{II}}$ and an intake of $\mathrm{Fe}^{\mathrm{II}}$. When $\mathrm{Fe}$ is limiting, the response of these plants includes the induction, in a coordinated form, of the $\mathrm{Fe}^{\mathrm{III}}$-reduction activity at the root surface and the $\mathrm{Fe}^{\mathrm{II}}$ transport across the root epidermal cell membrane (Connolly et al. 2003). In addition, there is an enhanced release of protons and a subsequent acidification of the rhizosphere, which affects the levels of $\mathrm{Fe}$ in the rhizosphere and creates a more favorable environment for the $\mathrm{Fe}^{\mathrm{III}}$-chelate reductase activity. However, in monocots, $\mathrm{Fe}$ uptake is based on chelation of $\mathrm{Fe}^{\mathrm{III}}$ to strong ligands (phytosiderophores, $\mathrm{PS}_{\mathrm{s}}$ ) belonging to the mugineic acids' (MAs) family. These ligands are released into the rhizosphere where they can form chelates with the metal, which are then taken up as a complex by a specific transporter (strategy II, Ma et al. 1995; Von Wiren et al. 1994). Under Fe-deficient conditions, $\mathrm{PS}_{\mathrm{s}}$ secretion into the rhizosphere and biosynthesis of $\mathrm{Ps}_{\mathrm{s}}$ in plant tissues are markedly increased (Nagasaka et al. 2009), with positive effect in the $\mathrm{PS}_{\mathrm{s}}$-mediated Femobilization process in the rhizosphere. It is interesting to note that rice, a strategy II plant releasing $\mathrm{PS}_{\mathrm{s}}\left(2^{\prime}-\right.$ deoxymugineic acid [DMA]) and taking up the entire $\mathrm{Fe}^{\mathrm{III}}-$ PS complexes, is also able to take up directly $\mathrm{Fe}^{\mathrm{II}}$ from the soil solution, definitely an advantage when rice is cultivated in submerged conditions (Ishimaru et al. 2006). On the contrary, it has been recently demonstrated that a $\mathrm{Fe}^{\mathrm{III}}$ complex with DMA, a $\mathrm{PS}_{\mathrm{s}}$ released by maize roots, could be absorbed directly by roots of a neighboring dicot using a transporter codified by a gene belonging to the yellow stripe1-like (YSL) family and located at the root epidermis (Xiong et al. 2013), representing a valid opportunity in Fe acquisition process of dicots when intercropped with monocots. With respect to the possibility that plants could utilize $\mathrm{Fe}^{\mathrm{III}}-\mathrm{MS}_{\mathrm{s}}$ complexes as $\mathrm{Fe}$ source, due to their very high stability constant, the Fe exchange between $\mathrm{Fe}^{\mathrm{III}}-\mathrm{MS}_{\mathrm{s}}$ and $\mathrm{PS}_{\mathrm{s}}$ could be very limited. Therefore, minimal could be the contribution of these microbial Fe complexes to the Fe acquisition of grasses (strategy II plants) via the "ligand exchange" mechanism, as yet described in barley when Fe was supplied as complex with a humic fraction (Cesco et al. 2002) having an estimated stability constant of $10^{13}$ (Takahashi et al. 1997). In any case, strategy
II plants are able to use, although to a low extent, Fe from $\mathrm{Fe}^{\mathrm{III}}-\mathrm{MS}_{\mathrm{s}}$ complexes via, at least in part, indirect mechanisms (Duijff et al. 1994; Robin et al. 2008). Also for plants belonging to strategy I (dicots), an impact of $\mathrm{Fe}^{\mathrm{III}}-\mathrm{MS}_{\mathrm{s}}$ on the micronutrient nutrition has been assessed (see also Lemanceau et al. 2009), with the hypothesis of the involvement of a putative transporter different than IRT1 for the uptake of the integral $\mathrm{Fe}^{\mathrm{III}}-\mathrm{MS}_{\mathrm{s}}$ complex (Vansuyt et al. 2007). On the other hand, plant-derived $\mathrm{Fe}-\mathrm{PS}_{\mathrm{S}}$ or $\mathrm{Fe}$-organic acids (like $\mathrm{Fe}$ citrate) complexes can be a good source of nutrient $(\mathrm{Fe})$ and energy (via $\mathrm{PS}_{\mathrm{s}}$ and organic compound degradation), inducing the microbes to depress the release of their own $\mathrm{MS}_{\mathrm{s}}$ and taking advantage of the Fe mobilized by these plant chelators (Marschner and Crowley 1998; Von Wiren et al. 1993; Jones 1998). For these reasons, microorganisms appear to be highly competitive for Fe compared with plant roots.

$\mathrm{Fe}$ acquisition by plants and microbes, which result in the removal of soluble Fe from the rhizosphere solution, is able to affect the chemical equilibria between the different $\mathrm{Fe}$ forms and therefore the extent of the weathering of Fe-bearing minerals in this specific volume of soil. Where the Fe uptake mechanism is based on the acquisition of $\mathrm{Fe}^{\mathrm{III}}$ in a chelated form with $\mathrm{PS}_{\mathrm{s}}$ (monocots, strategy II) or $\mathrm{MS}_{\mathrm{s}}$ (microbes), the depletion of $\mathrm{Fe}$ in the rhizospheric solution occurs simultaneously with that of the ligands $\left(\mathrm{PS}_{\mathrm{s}}\right.$ and/or $\left.\mathrm{MS}_{\mathrm{s}}\right)$. However, in strategy I plants, because the intake in root cell of $\mathrm{Fe}^{\mathrm{II}}$ is in its ionic form, the $\mathrm{Fe}$ acquisition process has an impact on the $\mathrm{Fe}$ concentration in the rhizosphere but not on the availability of ligands that could, theoretically, mediate the Fe-mobilization process after their release. As a consequence, the weathering of Fe-bearing soil components could be even more accelerated.

\section{Factors influencing $\mathrm{Fe}$ availability in soils}

Iron release by weathering of soil mineral sources is a very slow process, regulated by $\mathrm{pH}$ and $\mathrm{O}_{2}$ concentration and by the dissolution-precipitation phenomena (Mengel 1994; Lindsay 1988). Once mobilized in weathering processes, the fate of $\mathrm{Fe}^{\mathrm{II}}$ is largely dependent both on the redox reaction and on $\mathrm{pH}$ conditions of the soil environment. In particular, under aerobic conditions and at $\mathrm{pH}$ values ranging from 5 to $8, \mathrm{Fe}^{\mathrm{II}}$ released from primary minerals of soils is readily oxidized. Under anoxic conditions, $\mathrm{Fe}^{\mathrm{III}}$ is readily reduced either by inorganic chemical reactions or by microbial processes. The same biological processes occurring in soil and related with the Fe cycle are shown in Fig. 2. The weathering of soil mineral sources with a subsequent release of $\mathrm{Fe}$ could be affected by soil microbes through their involvement in redox, complexation, and acidification processes. The extent of these phenomena is closely dependent on the availability of organic 
molecules (organic carbon) from which the microbes obtain sustenance.

\subsection{Redox processes}

Bacteria can reduce $\mathrm{Fe}^{\mathrm{III}}$ both directly and indirectly (Fortin and Langley 2005). In the first case, the enzymatic reduction of $\mathrm{Fe}^{\mathrm{III}}$ to $\mathrm{Fe}^{\mathrm{II}}$ gains energy in contrast, in the second one, modification of $\mathrm{pH}$ and $\mathrm{Eh}$ conditions could promote $\mathrm{Fe}$ solubilization at low $\mathrm{pH}$ and/or its precipitation in alkaline conditions.

In the absence of oxygen, $\mathrm{Fe}^{\mathrm{III}}$ oxides can be used as a terminal electron acceptor (TEA) during microbial respiration (Lovley et al. 2004). In this process, termed enzymatic dissimilatory Fe reduction (DIR; Lovley 1991), bacteria couple hydrogen and organic carbon oxidation to the reduction of $\mathrm{Fe}^{\mathrm{III}}$. Dissimilatory Fe-reducing bacteria can utilize $\mathrm{Fe}^{\mathrm{III}}$ from a wide variety of Fe oxides and clay minerals.

In aerate conditions, microbial oxidation of minerals containing $\mathrm{Fe}^{\mathrm{II}}$ can be accelerated by a wide range of Fe-oxidizing bacteria under both acidic/neutral $\mathrm{pH}$ conditions. Microorganisms that are able to oxidize $\mathrm{Fe}^{\mathrm{II}}$ are generally divided into two groups in function of $\mathrm{pH}$ : the acidophilic and neutrophilic bacteria. Many aerobic acidophilic microorganisms are able to couple $\mathrm{Fe}^{\mathrm{II}}$ oxidation to growth to the reduction of nitrate (Fig. 1). Acidophilic microbes such as Acidothiobacillus ferrooxidans have been observed to be capable of aerobic respiration on both $\mathrm{Fe}^{\mathrm{II}}$ and reduced sulfur (Baker and Banfield 2003). At neutral $\mathrm{pH}, \mathrm{Fe}^{\mathrm{II}}$ is subject to rapid chemical oxidation in relation to $\mathrm{O}_{2}$ concentration, and the $\mathrm{Fe}^{\mathrm{III}}$ that is produced quickly hydrolyzes and precipitates as Fe hydroxides or oxyhydroxides. Due to the fast rate of this spontaneous reaction, the activity of neutrophilic bacteria has generally been considered very slow (Sobolev and Roden 2004). Recently, the presence of $\mathrm{Fe}^{\mathrm{III}}$ precipitates associated with the activity of many neutrophilic bacteria (Gallionella and Leptothrix species) observed in a variety of soil and water environments suggests that microbial $\mathrm{Fe}^{\mathrm{II}}$ oxidation can successfully compete with $\mathrm{Fe}^{\mathrm{II}}$ abiotic oxidation (Weiss et al. 2004, 2005; Duckworth et al. 2009).

Dissimilatory Fe-reducing bacteria can also consume Mn and some other elements during their activity accumulating, selectively, some of them in paddy soils. As the redox potential of most waterlogged soils tends to approach $0 \mathrm{~V}, \mathrm{Fe}^{\mathrm{II}}$ is the predominant Fe species in a solution as in flooded soil dedicated for rice cultivation. In this condition, like in paddy soils, the benefit for plants could derive from the high $\mathrm{Fe}^{\mathrm{II}}$ solubility (about three orders of magnitude greater than $\mathrm{Fe}^{\mathrm{III}}$; Fiedler et al. 2007) and thus able to guarantee higher levels of Fe availability for plants. However, in cultivated soils, due to their redox fluctuation, most of soluble $\mathrm{Fe}$ is present in the $\mathrm{Fe}^{\mathrm{III}}$ form with the exception of poorly drained soils, where the quantity of its $\mathrm{Fe}^{\mathrm{II}}$ form could reach sufficient levels for plant uptake (Lindsay 1979, 1988). In fact, under waterlogged conditions, where the redox potential is low $(\mathrm{Eh}<0.4 \mathrm{~V})$ and the $\mathrm{pH}$ is below $5, \mathrm{Fe}^{\mathrm{III}}$ is easily reduced to $\mathrm{Fe}^{\mathrm{II}}$ by reducing bacteria, thus increasing consistently the micronutrient solubility (Borch et al. 2010). Microbial sulfidogenesis can strongly affect $\mathrm{Fe}$ geochemistry through a variety of processes. A predominant reduction of $\mathrm{Fe}^{\mathrm{III}}$ is observed in acid sulfate soil characterized by redox potential $<0.4 \mathrm{~V}$ and strong acidity $(\mathrm{pH}<4)$. In anaerobic conditions, dissimilatory $\mathrm{SO}_{4}{ }^{2-}$ reducing bacteria (Desulfotomaculum or Desulfosporosinus) can drive the rapid reductive dissolution of poorly ordered ferric (hydr)oxides, such as ferrihydrite (Stackebrandt et al. 1997; Stubner 2002). In addition, sulfidogenesis can also sequester $\mathrm{Fe}$ by facilitating the precipitation of Fe-sulfide minerals such as pyrite (Burton et al. 2009, 2011). This is one of the most common microbial reactions in anaerobic soils (Fig. 3). Problems arise when the oxidation of Fe sulfides exceeds the $\mathrm{pH}$ buffering capacity of the soil. Acid sulfate soils produced by drainage become severely acid within weeks or months. Usually, they can be identified by straw yellow mottles of jarosite, $\mathrm{KFe}_{3}\left(\mathrm{SO}_{4}\right)_{2}(\mathrm{OH})_{6}$, that develop on the soil surface. The major limitation to soil productivity often is not the acidity of the soil itself but increased $\mathrm{Al}$ and $\mathrm{Mn}$ toxicity to plants caused by the release of these elements due to the acidification. The acidification of these soils results mainly from microbial oxidation of pyrite when reducing conditions change and oxygen is increased. The gradual restoration of aerobic conditions at neutral $\mathrm{pH}$, contemporary with the increase of Eh values, can lead to a formation of Fe-Mn nodules. The shift from anoxic to oxic conditions and vice versa can frequently occur in cultivated soils like poorly drained soils, while anaerobic condition can be a prolonged condition in the growing period of rice in paddy-cultivation systems typical of wetland. It has been clearly observed that the shift from oxic to anoxic soil condition is accompanied by a progressive $\mathrm{Fe}$ transformation from $\mathrm{Fe}^{\mathrm{III}}$ to $\mathrm{Fe}^{\mathrm{II}}$ forms (Munch and Ottow 1980). Many paddy soils are the result of specific agronomic practices of soil management, e.g., to optimize rice cultivation. This management-induced change forms oxic to anoxic environment, which results in temporal and spatial (vertical and horizontal) variations of redox reactions, which, in turn, affect the dynamics of organic and mineral constituents (Cheng et al. 2009). The translocation of Fe can also occur in various directions and by different processes (including eluviation and illuviation) starting from the reduction of $\mathrm{Fe}^{\mathrm{III}}$. In this latter reaction, also $\mathrm{Fe}^{\mathrm{III}}$ in the crystal structures of primary minerals can be reduced by the activity of indigenous microbes. In poorly drained soils, where anoxic conditions are frequent and present for long period of times, the drainage of water, following a submersion period, may result in an increase of oxygen availability with a rapid oxidation of $\mathrm{Fe}^{\mathrm{II}}$; this redox reaction favors, in turn, the formation of a shortrange-ordered hydroxide, such as ferrihydrite or crystalline 
Fig. 3 Different pathways of iron oxides bacteria interactions.

Many mechanisms (solubilization [chelation], biotransformation, precipitation, and degradation) processes are involved in the dissolution of $\mathrm{Fe}$ in soil (adapted from Tabak et al. 2005)
Bioweathering

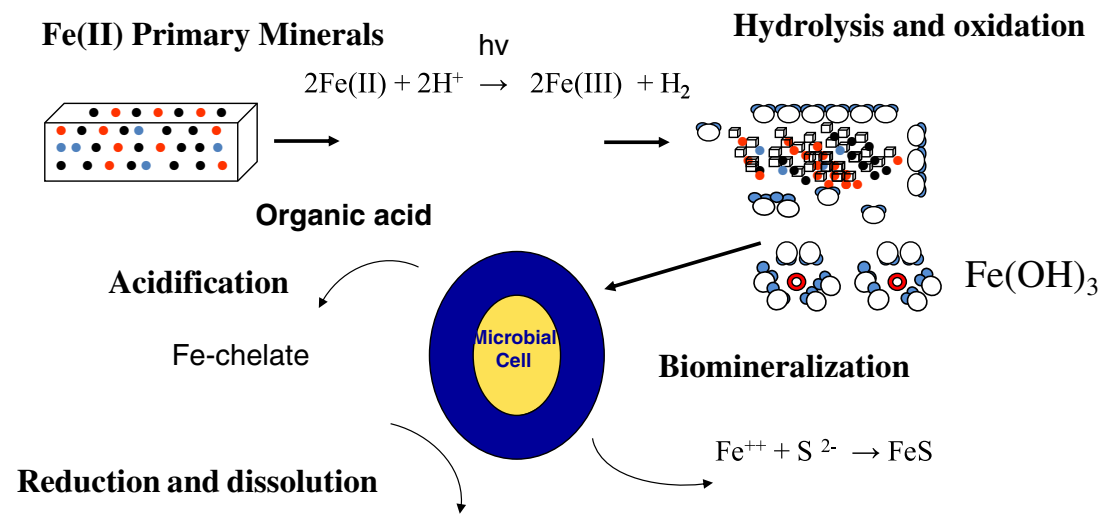

$\mathrm{Fe}(\mathrm{III})$ reduction to $\mathrm{Fe}(\mathrm{II})$ oxides like lepidocrocite, goethite, and maghemite in $\mathrm{Fe}-\mathrm{Mn}$ nodules (Liu et al. 2002). The differences in reducibility between the various $\mathrm{Fe}^{\mathrm{III}}$ (hydr)oxides can be explained by differences in reactive surface area and follows the same order as the reactivity order of these minerals with respect to sulphidication processes, which is ferrihydrite $>$ lepidocrocite $>$ goethite $>$ hematite. Although the reducibility of crystalline $\mathrm{Fe}^{\mathrm{III}}$ (hydr)oxides is much lower than that of amorphous $\mathrm{Fe}^{\mathrm{III}}$ (hydr)oxides, the contribution of crystalline phases to total Fe reduction can be highly significant, up to $10-20 \%$ in some soils (Roden and Zachara 1996; Jakobsen and Postma 1999).

\subsection{Fe complexation processes}

With respect to the Fe geochemistry in soil, $\mathrm{MS}_{\mathrm{s}}$ are able to react directly with the surfaces of Fe minerals mobilizing the micronutrient via a complexation process (Kostka et al. 1996). The insoluble Fe sources mainly subjected to weathering by $\mathrm{MS}_{\mathrm{s}}$ are Fe-containing primary silicates and $\mathrm{Fe}$ (hydr)oxides (Kraemer 2004). It has been observed that the smaller the particles, the greater (tenfold) the dissolution rate of these particles; in particular, those with sub-10 nm size are particularly available to aerobic microbes and, following the attack by $\mathrm{MS}_{\mathrm{s}}$, able to guarantee sufficient $\mathrm{Fe}$ for bacterial growth (Treeby et al. 1989). In addition to Fe minerals, $\mathrm{MS}_{\mathrm{s}}$ may also be able to remove Fe from organic complexes (like Fe complexed by organic acids, phenols, soil humic substances [HS], etc.) via ligand exchange, as also described for $\mathrm{PS}_{\mathrm{s}}$ and $\mathrm{Fe}-\mathrm{HS}$ (Cesco et al. 2000). Part of these organic ligands may be released by plants in the rhizosphere, particularly under $\mathrm{Fe}$ shortage, organic acids (Jones 1998) and phenolics, being the most represented. For instance, for soils where Fe oxides are responsible of phosphate fixation (Borggaard et al. 1990; Colombo et al. 1994; Hinsinger 2001), low-molecularweight organic acids can favor the availability of phosphate for plants through an exchange process of the anion adsorbed to Fe oxides (Liu et al. 1999). An analogous process has been described for flavonoids and citrate released by roots of white lupin, which, solubilizing $\mathrm{Fe}$ from an insoluble Fe phosphate, favored indirectly the mobilization and the availability of phosphate (Shaw et al. 2006; Tomasi et al. 2008). With respect to $\mathrm{Fe}$, it has been demonstrated that the Fe-mobilization capacity of these organic ligands (Cesco et al. 2000, 2010) and the contribution of their Fe complexes in the acquisition process of the micronutrient by plants (Cesco et al. 2002, 2006; Pinton et al. 1999; Tomasi et al. 2009a, b) could be quite different among the complexes. In the mobilization process, $\mathrm{MS}_{\mathrm{s}}$ can act alone or in combination with simple carboxylic acids and organic reducing agents of different origin; in this combined form, an additive effect with an enhanced extent of $\mathrm{Fe}$ dissolution from minerals has been observed (Dhungana et al. 2007; Dehner et al. 2010). Among the organic molecules detected in the rhizosphere in addition to $\mathrm{MS}_{\mathrm{s}}$, oxalate needs to be mentioned as for its abundance among rhizodepositions and for its direct involvement in the biological and efficient weathering of minerals (Jones and Wilson 1985; Adamo et al. 1997). Flavonoids released by roots have a direct effect on soil minerals and on biological activity in the soil that play an important role in $\mathrm{Fe}$ solubilization processes (El Hajji et al. 2006; Tomasi et al. 2008; Cesco et al. 2012). However, although the impact of flavonoids on soil microorganisms could also be of relevance in terms of microbe-mediated $\mathrm{Fe}$ oxidation-reduction in soil (Tomasi et al. 2008; Cesco et al. 2010, 2012), the relative contribution of these molecules to the Fe availability in the rhizosphere and to the use of this Fe source for plant nutrient acquisition has not yet been comprehensively studied. It appears evident that the release of $\mathrm{Fe}^{\mathrm{III}}$-complexing organic compounds by roots and microorganisms can contribute to $\mathrm{Fe}$ (hydr)oxides dissolution and/or to $\mathrm{Fe}$ mobilization from unavailable sources (see Figs. 1 and 2). Iron complexing organic compounds are considered the main part of soluble 
$\mathrm{Fe}^{\mathrm{III}}$ species in soil and are of real relevance particularly in an agricultural context (Hinsinger 1998; van Hees and Lundstrom 2000; Hinsinger 2001). This aspect is even more important when calcareous soils are considered; in fact, the $\mathrm{pH}$ values of calcareous soils are so unfavorable to the solubility of $\mathrm{Fe}$ ions that these induce very often the onset of severe Fedeficient symptoms in cultivated plants (Loeppert et al. 1984; Marschner and Römheld 1994; de Santiago and Delgado 2006). There are vast differences in the ability of the various organic chelates to maintain soluble $\mathrm{Fe}$ in soil solution. The order of decreasing ability of five natural and synthetic organic compounds to chelate $\mathrm{Fe}$ in soils is as follows: EDDHA> DTPA $>$ EDTA $>$ citric acid $>$ oxalic acid (Lindsay 1979). The natural organic acids (citric and oxalic) are not effective chelators above $\mathrm{pH} \mathrm{7,} \mathrm{while} \mathrm{only} \mathrm{EDDHA} \mathrm{and} \mathrm{DTPA} \mathrm{have} \mathrm{the}$ ability to chelate significant amounts of $\mathrm{Fe}$ in the $\mathrm{pH}$ range above 7.0. These equilibrium relationships are typical of those generally observed when these chelates are used as Fe fertilizers in soils of different $\mathrm{pH}$. However, it is necessary to highlight that $\mathrm{Fe}$ solubility in soil depends not only on $\mathrm{pH}$ values and on the concentration of the organic ligands present but also on the oxidation state of soil (Lindsay 1988).

\subsection{Soil pH: acidification and alkalinization of the soil environment}

The solubility of Fe-bearing minerals is controlled by dissolution-precipitation equilibria, and its extent is dependent on soil $\mathrm{pH}$ and ionic strength. Iron as trivalent ions exists only at very low $\mathrm{pH}$ values $(\mathrm{pH}<3)$ while at neutral $\mathrm{pH}$, the solubility of $\mathrm{Fe}^{\mathrm{III}}$ drops off very fast. At neutral $\mathrm{pH}, \mathrm{Fe}$ oxides reach a minimum solubility near $10^{-10} \mathrm{M}$, at $\mathrm{pH}$ range of 7.5-8.5 (Lindsay and Schwab 1982). In soil with low Fe availability, bacteria and many graminaceous plants in response to $\mathrm{Fe}$ shortage have developed different strategies to solubilize Fe by improving soil acidity and producing chelating compounds. The latter are released as simple low-molecularweight organic acids and many other complex molecules known as rhizodeposits. The lower the $\mathrm{pH}$ of soil solution, the higher is the availability of soluble Fe (Robin et al. 2008). In this regard, microbes are able to give their contribution to soil acidification with their metabolism. In fact, thanks to their respiration, the $p \mathrm{CO}_{2}$ is increased, enhancing the concentration of carbonic acid (Hinsinger et al. 2003); furthermore, bacteria involved in the oxidation of ferrous Fe sulfide, such as pyrite, and in that of ammonium leading to the formation of sulfuric and nitric acids are also able to acidify the surrounding soil (Yu and Bishop 2001). To this phenomenon of rhizosphere acidification, plants, with their roots, take part also. In fact, rhizosphere $\mathrm{pH}$ has been reported to be up to $1-2 \mathrm{pH}$ units below or above bulk soil $\mathrm{pH}$; in addition to the metabolism of roots, carboxylate release of these tissues in the rhizosphere, when the exudation is coupled with proton efflux, can cause a significant decrease of the $\mathrm{pH}$ of this specific volume of soil. A link between organic acid excretion and proton extrusion by roots of white lupin has been clearly demonstrated (Tomasi et al. 2009a, b). Plasma membrane $\mathrm{H}^{+}$ATPase activity of roots, mainly involved in the proton extrusion coupled with the release of citrate previously described, is known also for being stimulated by soil HS (Pinton et al. 1997a). In soils with low Fe availability, the occurrence of organic acid (citric, malic, and oxalic) also contributes to $\mathrm{pH}$ decrease when their exudation is coupled with proton efflux; the concentration in the rizodeposition varies among plant species and depends on soil pH (Hinsinger et al. 2003). Small organic acids from bacterial metabolism also contribute to $\mathrm{pH}$ decrease. This is the case for oxalic acid, which is produced in large amounts by fungi and lichens (Jones and Wilson 1985). With respect to the mineral weathering, dissolution reactions by protons are generally considered to be the rate-determining step for weathering processes in acidic condition; on the contrary, in soil environment and sediments, due to prevailing neutral conditions, proton-promoted dissolution of primary Fe-bearing minerals is neglectable.

\section{Soil organic carbon related with iron cycle}

Bacteria can obtain sustenance from organic molecules, often exuded by plant roots and derived from the decomposition of soil organic matter (Lovley 1991). Therefore, the activity of bacteria is strictly dependent on the availability of organic carbon. In this context, the interaction between bacteria and Fe minerals appears to be sustained by plant action, specifically root exudation of complex organic compounds used by bacteria as a source for their sustenance. In fact, the weathering of these minerals can be strongly accelerated by the activities of living organisms, as shown for microorganisms and plants (Welch et al. 1999; Baker and Banfield 2003; Hansel et al. 2004; Liu et al. 2006). Organic matter decomposition is one of the most important processes linked with the Fe cycle in soil environment. In cold-temperate climates, the carbon storage in Spodosols is largely a function of the contents of crystalline $\mathrm{Fe}$ and poorly crystalline hydroxides (Wiseman and Püttmann 2005). In hot, humid climates, the intense microbial activity that rapidly and completely mineralizes available organic matter prevents extensive formation of poorly ordered $\mathrm{Fe}$ minerals. Bacteria and fungi can use a wide spectrum of organic compounds, such as cellulose, pectin, lignin, tannine, lignocellulose, sugars, organic acids, and amino acids and are able to generate more complex molecules precursors of HS. With respect to HS, for their complex nature and thus poor decomposability, they are not able to stimulate in a similar extent as root exudates the growth and activity of soil microorganisms. On the other hand, HS could also act directly in the processes related to the soil $\mathrm{Fe}$ chemistry by 
improving the solubility of $\mathrm{Fe}$ in soil at concentration much higher than those achievable exclusively with chemical-dissolution reactions (Schnitzer 1978; Stevenson 1994; Colombo et al. 2012). Depending on molecular size and solubility of HS fractions, the stability and mobility of complexes of HS with $\mathrm{Fe}^{\mathrm{III}}$ in soil vary with the $\mathrm{pH}$ and redox potential (Eh). The solubility of soil $\mathrm{Fe}$ is considerably increased by the chelation of $\mathrm{Fe}^{\mathrm{III}}$ with organic ligands that make up the dissolved organic matter or other soluble macromolecules with carboxylic or polyphenolic functional groups (Schwertmann 1990) and more complex and diverse macromolecules constitutive of insoluble HS (Stevenson 1994). The capability of HS to form complexes with metals in soils, especially cationic micronutrients, is well known. As a consequence of this process, the solubility of many nutrients can be consistently modified, and this phenomenon is especially true and relevant for those metals, like Fe, whose solubility is regulated by the formation of insoluble hydroxides. With regard to Fe availability, molecular size and solubility of HS are important factors to consider. HS fractions with high molecular mass, which are mostly insoluble, can hold quite large amounts of the metal, especially in alkaline environments. Thus, $\mathrm{Fe}^{\mathrm{III}}$ is subtracted from its available pool via precipitation and subsequent crystallization processes (Schwertmann 1991). Differently, HS fractions with low molecular mass, like fulvic acids, can contribute to the available pool of Fe present in soil solution due to their solubility and capability in forming $\mathrm{Fe}$ complexes. With respect to these low-molecular-weight humic fractions, it has been clearly demonstrated that they can act efficiently as natural substrates for $\mathrm{Fe}$ acquisition by roots of monocots and dicots (Pinton et al. 1997b, 1999; Cesco et al. 2002). HS increase Fe bioavailability through their Fechelating properties and have redox-reactive properties (Kögel-Knabner et al. 2008). These properties are related to phenolic groups contributing to $\mathrm{Fe}^{\mathrm{III}}$ reduction. The chemical reduction of $\mathrm{Fe}^{\mathrm{III}}$ by $\mathrm{HS}$ is strongly $\mathrm{pH}$ dependent; as $\mathrm{pH}$ increases, HS are more frequently bound to metal cations and therefore have a decreased reducing ability. In soils with changing redox conditions, HS may act as redox buffers by accepting electrons from microbial respiration under anoxic conditions (Heitmann et al. 2007) and, upon re-aeration, by donating electrons to oxygen. This process is very important in peatlands and bogs, where it is believed to significantly decrease methanogenesis. In addition to acting as redox buffers, HS mediate chemical redox reactions, including the transfer of electrons from microorganisms to poorly accessible mineral phases, such as $\mathrm{Fe}^{\mathrm{III}}$ oxides (Bauer and Kappler 2009; Kögel-Knabner et al. 2010). Lalonde et al. (2012) proposed that the associations between organic matter and $\mathrm{Fe}$ are formed primarily through co-precipitation and/or direct chelation; these processes are able to promote the preservation of organic carbon in marine sediments and act as a key factor in the long-term storage of organic carbon. The reason could be related with the biological interactions with nano-Fe oxide particles that are strongly associated with organic matter. Such organic molecules may for instance interact in acid or neutral condition with Fe oxide particles by gradual solubilization or by oxidation of $\mathrm{Fe}^{\mathrm{II}}$ from primary minerals. Natural and anthropogenic changes in climate and global biogeochemistry will alter the mobility of $\mathrm{Fe}$ and other trace metals to the soil, which may cause changes of soil carbon dynamic.

\section{Conclusions}

Plant, microbes, and Fe oxides coexist in soils, and their close association provides ample opportunities for mutual interactions with an impact on mineral weathering of primary $\mathrm{Fe}$ minerals and on the availability of this nutrient for microbe and plant growth.

In cultivated soils (aerobic conditions), $\mathrm{Fe}$ is mostly oxidized and precipitated as ferric oxides with low availability for plants. In order to cope with the Fe shortage, the release of exudates (Fe-complexing organic compounds, e.g., $\mathrm{PS}_{\mathrm{s}}$ and organic acids) by roots results also in an effect on microbial density and activity. The high demand for $\mathrm{Fe}$ in the soil together with its low availability in soils leads to a competition between plant and other living organisms, being particularly strong in alkaline soils. A better understanding of these phenomena could be surely of relevance also in identifying effective solutions for remedying Fe deficiency or, alternatively, restricting the onset of its symptoms and yield limitations in crops.

In paddy and poorly drained soils (anaerobic conditions), microbes can catalyze the reduction of $\mathrm{Fe}^{\mathrm{III}}$ for their energy needs by coupling oxidation of organic matter to the $\mathrm{Fe}$ reduction. In this context, microbial metabolism is reputed to play an important role in controlling $\mathrm{Fe}^{\mathrm{III}}$-reduction chemistry. Differently, in aerated soils, Fe oxidation is considered a major process involved in the decomposition of organic matter and can play an important role in the stabilization of organic carbon.

In cold and temperate climates, the carbon storage in aerobic soils (Spodosols, Andosols, Hystosols, etc.) is largely a function of the contents of crystalline Fe and poorly crystalline (hydr)oxides, possibly due to the biological interactions with nano-Fe oxide particles. In particular, adsorption of HS on crystalline $\mathrm{Fe}$ oxides has become more relevant because of its impact on the carbon balance. Natural and anthropogenic changes in climate and global biogeochemistry will alter the mobility of $\mathrm{Fe}$ and other trace metals in the soil with consequences on the soil carbon dynamic.

The improved understanding of amounts and intensity of interaction between different species and forms of $\mathrm{Fe}$ and organic molecules in soil presents a major challenge in understanding the dynamics of the Fe biogeochemical cycle in soil. 
The understanding of the Fe biogeochemical cycle enables identification of means to remedy Fe deficiency or, alternatively, restrict the onset of symptoms of Fe deficiency and its limitations of crop yield. Development and testing of new analytical techniques and an integrated approach, which includes soil microbiology and soil chemistry, are essential to understand the Fe cycle. Thanks to the fast development of spectroscopic methods (Mossbauer spectroscopy and synchrotron-based X-ray spectroscopies), the high-resolution microscopic techniques (high-resolution transmission electron microscopy and atomic force microscopy), and the molecular biological approaches (including high-throughput sequencing and bioinformatics), it is now possible to examine the surface properties of metal oxides in order to improve the comprehensive understanding of the interaction processes of $\mathrm{Fe}^{\mathrm{III}}$ and $\mathrm{Fe}^{\mathrm{II}}$ with organic molecules and microbes.

Acknowledgments Colombo C. would like to thank the financial support from the CAS as Visiting Professor Programs 2011-2012 to the Research Centre for Eco-environmental Sciences of Beijing. This research was supported by grants from Italian MIUR (FIRB-Programma "Futuro in Ricerca" and PRIN), Free University of Bolzano (TN5056), and the Natural Science Foundation of China (51221892, 41090281). The authors would like to thank Dr. Rebeka Fijan and Dr. Tanja Mimmo (Free University of Bolzano, Italy) and Tom Thomas W. Crawford, Jr., Ph.D. (Director of Research Bio Huma Netics Inc.) for their critical revision of the manuscript.

\section{References}

Adamo P, Colombo C, Violante P (1997) Occurrence of poorly ordered Fe-rich phases at the interface between the lichen Stereocaulon vesuvianum and volcanic rock from Mt Vesuvius. Clay Miner 32: 453-461

Adriano AD (2001) Trace elements in terrestrial environments: biogeochemistry, bioavailability, and risks of metals, Springer, New York Advances in Agronomy 99:183-225

Albrecht-Gary AM, Crumbliss AL (1998) Coordination chemistry of siderophores: thermodynamics and kinetics of iron chelation and release. Met Ions Biol Syst 35:239-327

Baker BJ, Banfield JF (2003) Microbial communities in acid mine drainage. FEMS Microbiol Ecol 44:139-152

Bauer I, Kappler A (2009) Rates and extent of reduction of Fe(III) compounds and $\mathrm{O}_{2}$ by humic substances. Environ Sci Technol 43: 4902-4908

Borch T, Kretzschmar R, Kappler A, Van Cappellen P, Ginder-Vogel M, Voegelin A, Campbell K (2010) Biogeochemical redox processes and their impact on contaminant dynamics. Environ Sci Technol 44: $15-23$

Borggaard OK, Jorgensen SS, Moberg JP, Raben-Lange B (1990) Influence of organic matter on phosphate adsorption by aluminium and iron oxides in sandy soils. J Soil Sci 41:443-449

Boukhalfa H, Crumbliss AL (2002) Chemical aspects of siderophore mediated iron transport. Biometals 15:325-339

Burton ED, Bush RT, Sullivan LA, Hocking RK, Mitchell DRG, Johnston SG, Fitzpatrick RW, Raven M, McClure S, Jang LY (2009) Iron-monosulfide oxidation in natural sediments: resolving microbially-mediated $\mathrm{S}$ transformations using XANES, electron microscopy and selective extractions. Environ Sci Technol 43: 3128-3134

Burton ED, Bush RT, Johnston SG, Sullivan LA, Keene AF (2011) Sulfur biogeochemical cycling and novel $\mathrm{Fe}-\mathrm{S}$ mineralization pathways in a tidally re-flooded wetland. Geochim Cosmochim Acta. doi:10. 1016/j.gca.2011.03.020

Carrillo-Gonzáles R, Šimunek J, Sauvé S, Adriano D (2006) Mechanisms and pathways of trace elements mobility in soils. Adv Agron 91: $112-178$

Cesco S, Römheld V, Varanini Z, Pinton R (2000) Solubilization of iron by water-extractable humic substances. J Plant Nutr Soil Sci 163: 285-290

Cesco S, Nikolic M, Römheld V, Varanini Z, Pinton R (2002) Uptake of ${ }^{59} \mathrm{Fe}$ from soluble ${ }^{59} \mathrm{Fe}$-humate complexes by cucumber and barley plants. Plant Soil 241:121-128

Cesco S, Rombolà AD, Tagliavini M (2006) Phytosiderophores released by graminaceous species promote ${ }^{59} \mathrm{Fe}$ uptake in citrus. Plant Soil 287:223-233

Cesco S, Neumann G, Tomasi N, Pinton R, Weisskopf L (2010) Release of plant-borne flavonoids into the rhizosphere and their role in plant nutrition. Plant Soil 329:1-25

Cesco S, Mimmo T, Tonon G, Tomasi N, Pinton R, Terzano R, Neumann G, Weisskopf L (2012) Plant-borne flavonoids released into the rhizosphere: impact on soil bio-activities related to plant nutrition. A review. Biol Fertil Soils 48:123-149

Cheng YQ, Yang LZ, Cao ZH, Yin S (2009) Chronosequential changes of selected pedogenic properties in paddy soils as compared with nonpaddy soils. Geoderma 151:31-41

Colombo C, Torrent J (1991) Aggregation and iron oxides in Terra Rossa soils. Catena 18:51-59

Colombo C, Barrón V, Torrent J (1994) Phosphate adsorption and desorption in relation to morphology and crystal properties of synthetic hematites. Geochimica et Cosmochimica acta 58: 1261-1269

Colombo C, Palumbo G, Sellitto VM, Rizzardo C, Tomasi N, Pinton R, Cesco S (2012) Characteristics of insoluble, high molecular weight iron-humic substances used as plant iron sources. Soil Sci Soc Am J 76:1246-1256

Connolly EL, Campbell N, Grotz N, Prichard CL, Guerinot ML (2003) Overexpression of the FRO2 iron reductase confers tolerance to growth on low iron and uncovers post-transcriptional control. Plant Physiol 133:1102-1110

Cornell RM, Schwertmann U (2003) The iron oxides, 2nd edn. Wiley$\mathrm{VCH}$, Weinheim

Cornell RM, Giovanoli R, Schneider W (1989) Review of the hydrolysis of iron (III) and the crystallization of amorphous iron (III) hydroxide hydrate. J Chem Technol Biotechnol 46:115-134

de Santiago A, Delgado A (2006) Predicting iron chlorosis of Lupinus albus L. in calcareous Spanish soils from various iron extracts. Soil Sci Soc Am J 70:1945-1950

Dehner CA, Awaya JD, Maurice PA, DuBois JL (2010) Roles of siderophores, oxalate, and ascorbate in mobilization of iron from hematite by the aerobic bacterium Pseudomonas mendocina. Appl Environ Microbiol 76:2041-2048

Dhungana S, Anthony CR III, Hersman LE (2007) Effect of exogenous reductant on growth and iron mobilization from ferrihydrite by the Pseudomonas mendocina ymp strain. Appl Environ Microbiol 73: 3428-3430

Duckworth OW, Holmstrom SJM, Pena J, Sposito G (2009) Biogeochemistry of iron oxidation in a circumneutral freshwater habitat. Chem Geol 260:149-158

Duijff BJ, Bakker PAHM, Schippers B (1994) Ferric pseudobactin 358 as an iron source for carnation. J Plant Nutr 17:2069-2078

El Hajji H, Nkhili E, Tomao V, Dangles O (2006) Interactions of quercitin with iron and copper ions: complexation and autoxidation. Free Radic Res 40:303-320 
Fiedler S, Vepraskas MJ, Richardson JL (2007) Soil redox potential: importance, field measurements, and observations. Adv Agron 94:1-57

Fortin D, Langley S (2005) Formation and occurrence of biogenic ironrich minerals. Earth-Sci Rev 72:1-19

Guerinot ML (1994) Microbial iron transport. Annu Rev Microbiol 48: 743-772

Guerinot ML, Yi Y (1994) Iron: nutritious, noxious, and not readily available. Plant Physiol 104:815-820

Hansel CM, Benner SG, Nico P, Fendorf S (2004) Structural constraints of ferric (hydr)oxides on dissimilatory iron reduction and the fate of Fe(II). Geochim Cosmochim Acta 68:3217-3229

Heitmann T, Goldhammer T, Beer J, Blodau C (2007) Electron transfer of dissolved organic matter and its potential significance for anaerobic respiration in a northern bog. Glob Chang Biol 13(8):1771-1785

Hinsinger P (1998) How do plant roots acquire mineral nutrients? Chemical processes involved in the rhizosphere. Adv Agron 64: 225-265

Hinsinger P (2001) Bioavailability of soil inorganic P in the rhizosphere as affected by root-induced chemical changes: a review. Plant Soil 237:173-195

Hinsinger P, Plassard C, Tang C, Jaillard B (2003) Origins of rootmediated $\mathrm{pH}$ changes in the rhizosphere and their responses to environmental constraints: a review. Plant Soil 248:43-59

Ishimaru Y, Suzuki M, Tsukamoto T, Suzuki K, Nakazono M, Kobayashi T, Wada Y, Watanabe S, Matsuhashi S, Takahashi M et al (2006) Rice plants take up iron as an $\mathrm{Fe}^{3+}$-phytosiderophore and as $\mathrm{Fe}^{2+}$. Plant J 45:335-346

Jakobsen R, Postma D (1999) Redox zoning, rates of sulfate reduction and interactions with Fe-reduction and methanogenesis in a shallow sandy aquifer, Romo, Denmark. Geochim Cosmochim Acta 63: 137-151

Jones DL (1998) Organic acids in the rhizosphere - a critical review. Plant Soil 205:25-44

Jones D, Wilson MJ (1985) Chemical activity of lichens on mineral surfaces. Int Biodeterior 21:99-105

Kobayashi T, Nishizawa NK (2012) Iron uptake, translocation, and regulation in higher plants. Annu Rev Plant Biol 63:131-152

Kögel-Knabner I, Guggenberger G, Kleber M, Kandeler E, Kalbitz K, Scheu S, Eusterhues K, Leinweber P (2008) Organo-mineral associations in temperate soils: integrating biology, mineralogy, and organic matter chemistry. J Plant Nutr Soil Sci 171:61-82

Kögel-Knabner I, Amelung W, Cao X, Fiedler S, Frenzel P, Jahn R, Kalbitz K, Kölbl A, Schloter M (2010) Biogeochemistry of paddy soils. Geoderma 157:1-14

Kostka JE, Stucki JW, Nealson KH, Wu J (1996) Reduction of structural $\mathrm{Fe}(\mathrm{III})$ in smectite by a pure culture of Shewanella putrefaciens strain MR-1. Clay Clay Miner 44:522-529

Kraemer SM (2004) Iron oxide dissolution and solubility in the presence of siderophores. Aquat Sci 66:3-18

Lalonde K, Mucci A, Ouellet A, Gélinas Y (2012) Preservation of organic matter in sediments promoted by iron. Nature 483:198-200

Lemanceau P, Expert D, Gaymard F, Bakker PAHM, Briat JF (2009) Role of iron in plant-microbe interactions. Adv Bot Res 51:491-549

Lindsay WL (1979) Chemical equilibria in soils. Wiley-Interscience, New York

Lindsay WL (1988) Solubility and redox equilibria of iron compounds in soils. In: Stucki JW (ed) Iron in soils and clay minerals. Reidel Publ. NATO, Dordrecht, pp 37-60

Lindsay WL, Schwab AP (1982) The chemistry of iron in soils and its availability to plants. J Plant Nutr 5:821-840

Liu F, He JZ, Colombo C, Violante A (1999) Competition in adsorption of sulfate and oxalate on goethite in absence and presence of phosphate. Soil Sci 1643:180-189

Liu F, Colombo C, Adamo P, He JZ, Violante A (2002) Manganese-iron nodules minerals associated with trace elements in Alfisols from China. Soil Sci Soc Am J 66:661-670
Liu W, Xu X, Wu X, Yang Q, Luo Y, Christie P (2006) Decomposition of silicate minerals by Bacillus mucilaginosus I liquid culture. Environ Geochem Health 28:133-140

Loeppert RH, Hossner LR, Chmielewski MA (1984) Indigenous soil properties influencing the availability of $\mathrm{Fe}$ in calcareous hot spots. J Plant Nutr 7:135-147

Loper JE, Buyer JS (1991) Siderophores in microbial interactions on plant surfaces. Mol Plant Microbe Interact 4:5-13

Lovley DR (1991) Dissimilatory Fe(III) and Mn(IV) reduction. Microbiol Rev 55:259-287

Lovley DR, Phillips EJP (1986) Organic matter mineralization with reduction of ferric iron in anaerobic sediments. Appl Environ Microbiol 51:683-689

Lovley DR, Phillips EJP (1988) Novel mode of microbial energy metabolism: organic carbon oxidation coupled to dissimilatory reduction of iron and manganese. Appl Environ Microbiol 54:1472-1480

Lovley DR, Holmes DE, Nevin KP (2004) Dissimilatory Fe(III) and Mn(IV) reduction. Adv Microb Physiol 49:219-286

Lowenstam HA (1981) Minerals formed by organisms. Science 211: 1126-1131

Lower SK, Hochella MF, Beveridge TJ (2001) Bacterial recognition of mineral surfaces: nanoscale interactions between Shewanella and $\alpha$ FeOOH. Science 292:1360-1363

Lucena JJ (2000) Effect of bicarbonate, nitrate and other environmental factors on iron deficiency chlorosis. A review. J Plant Nutr 23:15911606

Ma JF, Shinada T, Matsuda C, Nomoto K (1995) Biosynthesis of phytosiderophores, mugineic acids, associated with methionine cycling. J Biol Chem 270:16549-16554

Marschner P, Crowley DE (1998) Phytosiderophore decrease iron stress and pyo-verdine production of Pseudomonas fluorescens Pf-5 (pvdinaZ). Soil Biol Biochem 30:1275-e1280

Marschner H, Römheld V (1994) Strategies of plants for acquisition of iron. Plant Soil 165:261-274

Mengel K (1994) Iron availability in plants tissues-iron chlorosis on calcareous soils. Plant Soil 165:275-283

Mengel K, Kirkby E, Kosegarten H, Appel T (2001) Iron. In: Mengel K, Kirkby EA (eds) Mineral nutrition, 5th edn. Kluwer Academic Publishers, Dordrecht, pp 553-571

Munch JC, Ottow JCG (1980) Preferential reduction of amorphous to crystalline iron oxides by bacterial activity. J Soil Sci 129:15-21

Nagasaka S, Takahashi M, Nakanishi-Itai R, Bashir K, Nakanishi H, Mori S, Nishizawa NK (2009) Time-course analysis of gene expression over 24 hours in Fe-deficient barley roots. Plant Mol Biol 69:621631

Neilands JB (1981) Iron absorption and transport in microorganisms. Annu Rev Nutr 1:27-46

Pinton R, Cesco S, De Nobili M, Santi S, Varanini Z (1997a) Water- and pyrophosphate-extractable humic substances fractions as a source of iron for Fe-deficient cucumber plants. Biol Fertil Soils 26:23-27

Pinton R, Cesco S, Santi S, Varanini Z (1997b) Soil humic substances stimulate proton release by intact oat seedling roots. J Plant Nutr 20: 857-869

Pinton R, Cesco S, Santi S (1999) Water-extractable humic substances enhance iron deficiency responses by Fe-deficient cucumber plants. Plant Soil 210:145-157

Raaijmakers J, Van de Sluis L, Koster M, Bakker PAHM, Weisbeek PJ, Schippers B (1995) Utilisation of heterologous siderophores and rhizosphere competence of fluorescent Pseudomonas spp. Can J Microbiol 41:126-135

Robin A, Vansuyt G, Hinsinger P, Meyer JM, Briat JF, Lemanceau P (2008) Iron dynamics in the rhizosphere: consequences for plant health and nutrition. Adv Agron 99:83-225

Roden EE, Zachara JM (1996) Microbial reduction of crystalline iron(III) oxides: influence of oxides surface area and potential for cell growth. Environ Sci Technol 30:1618-1628 
Römheld V, Marschner H (1986) Mobilization of iron in rhizosphere of different plant species. In: Tinker PBH, Laüchli A (eds) Advances in plant nutrition, Volume 2. pp 155-204

Schnitzer M (1978) Humic substances: chemistry and reactions. In: Schnitzer M, Khan SU (eds) Soil organic matter. Elsevier, New York, pp 1-6

Schwertmann U (1985) The effect of pedogenic environments on iron oxide minerals. Adv Soil Sci 1:172-200

Schwertmann U (1988) Occurrence and formation of iron oxides in various pedoenvironments. In: Stucki JW, Goodman BA, Schwertmann U (eds) Iron in Soils, Clay Minerals. D. Reidel, Dordrecht, pp 267-308, \1

Schwertmann U (1990) Solubility and dissolution of iron oxides. In: Chen Y, Hadar Y (eds) Iron nutrition and interactions in plants. Kluwer Acad. Pub, Boston

Schwertmann U (1991) Solubility and dissolution of iron oxides. Plant Soil 130:1-25

Shaw LJ, Morris P, Hooker JE (2006) Perception and modification of plant flavonoid signals by rhizosphere microorganisms. Environ Microbiol 8:1867-1880

Sobolev D, Roden EE (2004) Characterization of a neutrophilic, chemolithoautotrophic $\mathrm{Fe}$ (II)-oxidizing beta-proteobacterium from freshwater wetland sediments. Geomicrobiol J 21:1-10

Sposito G (1989) The chemistry of soils. Oxford University Press, New York, $277 \mathrm{pp}$

Stackebrandt E, Sproer C, Rainey FA, Burghardt J, Pauker O, Hippe H (1997) Phylogenetic analysis of the genus Desulfotomaculum: evidence for the misclassification of Desulfotomaculum guttoideum and description of Desulfotomaculum orientis as Desulfosporosinus orientis gen. nov., comb. nov. Int J Syst Bacteriol 47:1134-1139

Stevenson FJ (1994) Humus chemistry: genesis, composition, reactions, 2nd edn. Wiley, New York, p 496

Stubner S (2002) Enumeration of ${ }^{16} \mathrm{~S}$ rDNA of Desulfotomaculum lineage 1 in rice field soil by real-time PCR with SybrGreen detection. J Microbiol Methods 50:155-164

Stucki JW, Lee K, Zhang L, Larson RA (2002) Effects of iron oxidation state on the surface and structural properties of smectites. Pure Appl Chem 74:2145-2158

Stumm W, Furrer G (1987) The dissolution of oxides and aluminium silicates: examples of surface-coordination-controlled kinetics. In: Stumm W (ed) Aquatic Surface Chemistry. John Wiley and Sons, New York, pp 197-219

Tabak HH, Lens P, van Hullebusch ED, Dejonghe W (2005) Developments in bioremediation of soils and sediments polluted with metals and radionuclides 1. Microbial processes and mechanisms affecting bioremediation of metal contamination and influencing metal toxicity and transport. Rev Environ Sci Bio/Technol 4:115-156

Takahashi Y, Minai Y, Ambe S, Makide Y, Ambe F, Tominaga T (1997) Simultaneous determination of stability constants of humate complexes with various metal ions using multitracer technique. Sci Total Environ 198:61-71
Tomasi N, Weisskopf L, Renella G, Landi L, Pinton R, Varanini Z, Nannipieri P, Torrent J, Martinoia E, Cesco S (2008) Flavonoids of white lupin roots participate in phosphorus mobilization from soil. Soil Biol Biochem 40:1971-1974

Tomasi N, Kretzschmar T, Espen L, Weisskopf L, Fuglsang AT, Palmgren MG, Neumann G, Varanini Z, Pinton R, Martinoia E, Cesco S (2009a) Plasma membrane H-ATPase-dependent citrate exudation from cluster roots of phosphate-deficient white lupin. Plant Cell Environ 32:465-475

Tomasi N, Rizzardo C, Monte R, Gottardi S, Jelali N, Terzano R, Vekemans B, De Nobili M, Varanini Z, Pinton R, Cesco S (2009b) Micro-analytical, physiological and molecular aspects of Fe acquisition in leaves of Fe-deficient tomato plants re-supplied with natural Fe-complexes in nutrient solution. Plant Soil 325:25-38

Torrent J, Cabedo A (1986) Sources of iron oxides in reddish brown soil profiles from calcarenites in Southern Spain. Geoderma 37:57-66

Treeby M, Marschner H, Romheld V (1989) Mobilization of iron and other micronutrient cations from calcareous soil by plant-borne, microbial, and synthetic metal chelators. Plant Soil 114:217-226

van Hees PAW, Lundstrom US (2000) Equilibrium models of aluminium and iron complexation with different organic acids in soil solution. Geoderma 94:201-221

Vansuyt G, Robin A, Briat JF, Curie C, Lemanceau P (2007) Iron acquisition from $\mathrm{Fe}$-pyoverdine by Arabidopsis thaliana. Mol Plant Microbe Interact 20:441-447

Von Wiren N, Roemheld V, Morel JL, Guckert A, Marschner H (1993) Influence of microorganisms on iron acquisition in maize. Soil Biol Biochem 25:371-376

Von Wiren N, Mori S, Marschner H, Römheld V (1994) Iron inefficiency in maize mutant ys1 (Zea mays L. cv Yellow-Stripe) is caused by a defect in uptake of iron phytosiderophores. Plant Physiol 106:71-77

Weiss JV, Emerson D, Megonigal JP (2004) Geochemical control of microbial $\mathrm{Fe}(\mathrm{III})$ reduction potential in wetlands: comparison of the rhizosphere to non-rhizosphere soil. FEMS Microbiol Ecol 48: $89-100$

Weiss JV, Emerson D, Megonigal JP (2005) Rhizosphere iron(III) deposition and reduction in a Juncus effusus L.-dominated wetland. Soil Sci Soc Am J 69:1861-1870

Welch SA, Barker WW, Banfield J (1999) Microbial extracellular polysacchrides and plagioclase dissolution. Geochim Cosmochim Acta 63:1405-1419

Wiseman CLS, Püttmann W (2005) Soil organic carbon and its sorptive preservation in central Germany. Eur J Soil Sci 56:65-76

Xiong H, Kakei Y, Kobayashi T, Guo X, Nakazono M, Takahashi H, Nakanishi H, Shen H, Zhanh F, Nishizawa NK, Zuo Y (2013) Molecular evidence for phytosiderophore-induced improvement of iron nutrition of peanut intercropped with maize in calcareous soil. Plant Cell Environ. doi:10.1111/pce.12097

Yu T, Bishop PL (2001) Stratification and oxidation-reduction potential change in an aerobic and sulfate-reducing biofilm studied using microelectrodes. Water Environ Res 73:368-373 